\title{
Open Government on Disaster Information Management in Regional Disaster Management Agency of South Sulawesi
}

\author{
Erwin Musdah $^{1}$, Anhar Dana Putra ${ }^{2}$ \\ \{erwinmusdah@stialanmakassar.ac.id ${ }^{1}$, anhardanaputra@stialanmakassar.ac.id ${ }^{2}$ \} \\ Sekolah Tinggi Ilmu Administrasi Lembaga Administrasi Negara, Jl. Andi Pangerang \\ Pettarani, Makassar, Indonesia ${ }^{1,2}$
}

\begin{abstract}
This study is aimed to discuss open government in the context of disaster information management in Disaster Management Agency (BPBD) of South Sulawesi. The study employs qualitative method and data was collected by interview, document study and observation. The informants of the study are BPBD and NGO which work in the disaster management sector. The result of the study shows that the principles of open government have been implemented in the disaster information management in BPBD, though not covering all stages of information management. The principle of transparency, participation and collaboration have been visible in the stage of collecting disaster information. In contrast, those initial principles are not visible in the stage of classifying information. In the stage of documenting and information service, these are found to be the principle of collaboration. Generally, BPBD does not maintain information transparency via website like others but focuses more on utilizing more accessible and practical media for users and disaster information sources like radios, flags, and social media. The openness of BPBD in disaster information management is influenced by some factors such as: (1) sources of disaster information are provided by various parties beside government (2) BPBD eagers to collaborate with other agencies. Lastly, disaster management needs a wide variety of specific skills.
\end{abstract}

Keywords. Open Government; Public Information Management; Disaster Information; Disaster Management

\section{Introduction}

This article aims to examine open government in the management of public information in the disaster sector. This topic is important because openness is still widely understood to be limited to publishing information about government activities. Information like this in the context of disaster management usually only encourages short-term action. In fact, disaster risk management activities are long and sustainable activities.

Disaster management is manifestation of the state purpose, which is to protect all the people of Indonesia. Although it is the responsibility of the government, disaster management is also carried out independently by community groups. Information about disasters is not only owned by the government but also by the community. The absence of a single source of information about disaster requires the government as the main actor in disaster management to be more open in terms of disaster information management. The government must be open to receive 
information from the public. On the contrary, the government must also open up disaster data so that it can be easily accessed by the public.

The concept of information disclosure which is supported by participation and collaboration between the government and the community is discussed in the concept of open government. In the concept of open government, an open government is a government that is transparent, participatory, and collaborative [1]. There have been many studies conducted to study open government. In general, the study discussed conceptual open government [1] [4], or practically in the context of governance in general [5] [7]. However, existing studies have not seen openness in governance in more specific areas such as public information management. Several studies have actually discussed about public information in the context of open government. However, that existing studies focus more on how public information is displayed using information systems technology [8][9]. Past studies have not reviewed the management of public information that includes information gathering to public information services. This study examines open government in disaster information management in South Sulawesi especially in the stages of gathering, classifying, documenting, and information services.

\section{Research Method}

This study uses a qualitative research method with interviews as the main data collection technique. Data from the interviews are supplemented with document studies and observations. This research was conducted at the Office of the Regional Disaster Management Agency of South Sulawesi Province (BPBD). Effective data collection was carried out in April to November 2018. The data collected was the result of in-depth interviews with six key informants namely the BPBD secretary, the head of the emergency and logistics section, the head of the rehabilitation section, the head of the prevention section, the head of emergency operation staff, and the disaster consultant from DVAT Embassy Australia. The interview data is supplemented by the results of a study of documents in the form of policies related to information management in South Sulawesi. We also made observations at the South Sulawesi Province BPBD office, website and social media related to managing information on the disaster in South Sulawesi.

\section{Result and Discussion}

\subsection{Disaster Information Management at BPBD South Sulawesi}

Republic of Indonesia Decree Number 14 Year 2018 on Public Information Disclosure gives the authority to the Information Management and Documentation Officer (PPID) to manage public information. In Article 1 it is explained that the Information Management and Documentation Officer is the responsible official for the storage, documentation, provision and / or information service in the public institution. PPID in carrying out its duties can be assisted by PPID assistant. South Sulawesi Provincial Government appoints PPID through South Sulawesi Governor Decree No. 1481 / VI / Year 2017 and PPID assistant through Governor Decree No. 1482 / VI / Year 2017. PPID South Sulawesi is assigned for Head of Information Communication and Statistics Office of South Sulawesi Province. PPID Assistant is assigned for officials in charge in Public Information Services and Functional Officials chaired by the Secretary or Head of Administration on the Regional Government Work Unit. At the Regional 
Disaster Management Agency, PPID assistant is assigned for the Secretary of BPBD South Sulawesi.

Public Information Management itself in South Sulawesi is regulated in South Sulawesi Governor Decree Number 115 Year 2017 on Guidelines for Information Management Services and Documentation of Local Government at South Sulawesi. In practice, the management of public information in BPBD South Sulawesi is still not running in accordance with the applicable regulations. The interviews with the Secretary of BPBD South Sulawesi revealed an interesting insight. Although the Governor's Decree has assigned the Secretary of BPBD ex officio as PPID Assistant, the Secretary of BPBD stated that there is no PPID structure in BPBD South Sulawesi (interview with AI on 4 May 2018). The statement may be due to personal ignorance of the Secretary of BPBD because he has recently been appointed to that position. But the statement that there is no structure of PPID in BPBD South Sulawesi is also justified by the Head of Rehabilitation Section BPBD South Sulawesi which is relatively long served on BPBD South Sulawesi (interview with ABR on May 3, 2018). The insights imply three things: first, the Governor's Decree on the PPID assistant is not known to the official concerned; secondly, there is no PPID Assistant structure in South Sulawesi BPBD, and thirdly, public information governance has certainly not run optimally as the rules applied. Public information management consists of four stages: information gathering, classification of information, documenting information, and information services. Public information governance in the Field of Disaster is described more clearly as follows:

Information Gathering. Information gathering is an activity related to accumulating activity which has been, is and will be executed by each work unit. Head of Prevention Unit of BPBD South Sulawesi explained that the information collecting process is done by each work unit in accordance with their job responsibility. In South Sulawesi BPBD there are three areas, namely Prevention and Preparedness, Logistics Emergency, and Rehabilitation and Reconstruction. Prevention and preparedness fields such as collecting data prior to disaster events such as disaster-prone maps, contingency plans etc., Emergency Field Logistics collects information on disaster events, while the Rehabilitation and Reconstruction field collects postdisaster data (interview with AU on May 4, 2018).

The process of gathering information at BPBD South Sulawesi is supported by cooperation and participation along with various parties. The BPBD Prevention and Preparedness works with BMKG for weather information or with ORARI for delivery of preparedness conditions. Field of Emergency and Logistics is in collaboration with the Department of Social Affairs, Tagana, PMI, SAR, TNI, POLRI etc. at the time of emergency disaster. Rehabilitation and Reconstruction Sector is in cooperation with PU to the reconstruction action (interview with MZ on May 4, 2018).

In the Field of Emergency of Logistics BPB South Sulawesi has a Central Control and Operational Unit (Pusat Pengendalian dan Operasional/Pusdalops) which has an important role in the management of disaster information. Pusdalops was formed based on Head of BNPB Regulation No. 15 Year 2015 on Guidelines for Establishment of Pusdalops PB. Pusdalops in South Sulawesi is a collaboration project and fully funded by DVAT Australia. One of the programs initiated by PUSDALOPS BPBD SUL-SEL is a digital application for smartphone users. This application has been available for download in Play Store since April 14, 2018. The Application of PUSDALOPS SUL-SEL is described on Play Store as a disaster monitoring application. In this application there are four functions namely E-Disaster, Emergency Call, Latest Disaster Information and Disaster Guidance. The first and second functions can be considered as information gathering functions. These two functions can be used to convey disasters to BPBD South Sulawesi. However, it seems this application has not been widely used 
by the community. One indication is seen from only four people who provide reviews about this application in the Play Store.

Besides PUSDALOPS BPBD application, information media utilized by BPBD South Sulawesi to collect information are Facebook group and WhatsApp group. The account name of Pusdalops Facebook group on Facebook is Pusdalops SulSel. On the account, it can be found many descriptions and photos of disaster events sent by BPBD from various districts / cities in South Sulawesi. Other social media that is used is WhatsApp group which become the media of coordination between BPBD and Quick Reaction Team all districts / cities as South Sulawesi. As disaster happening, information is submitted through the group using the format provided by BPBD South Sulawesi. The entire process was preceded by an explanation to each stakeholder regarding the format and mechanism for sharing disaster information through social media (interview with AD on May 3, 2018).

The Classification of Information. The classification stage of information is the stage of sorting out information that is suitable to open for public and information that is not. Conversely, information that is not suitable to open for public or excluded information means that it cannot be accessed by the public freely. The essence of this stage is on the sorting of information which may and should not be accessed. The result of interview indicates that there is no classification of information as described above in the practice of disaster management information at BPBD South Sulawesi. The decision on whether a data is accessible or not depends entirely on the leadership discretion. The Head of the Preparedness Section explained for the case of the same document may not be given to one person but given to another person. Leadership considerations are sometimes depending on who will use the information. Raw data for disaster risk maps may, for example, be inaccessible to the general public but accessible to universities (interview with MZ on 4 May 2018).

Documenting Information. The process of documenting information is a process for helping out the information services. In other words, documenting information is the process of archiving information. The results show that data storage is done by each work unit that collects information. Based on participatory observation conducted at field research in BPBD South Sulawesi, it can be concluded if documentation process is not going well. When there is a request for accessing documents between BPBD from various parties, there is no clear hints about who stored the documents. It is easy to find a related official will state that they did not know, merely because they had just been transferred to the position. From that situation, it can be understood that information documentation system is not well established in BPBD South Sulawesi.

Specifically, for disaster information, the documentation process in South Sulawesi BPBD was helped by the existence of a disaster information system developed by BNPB through the Disaster Data and Information website (DIBI). South Sulawesi BPBD Pusdalops staff explained that all disaster information was collected from various parties, the Pusdalops immediately verified the data and entered the data on the DIBI website (interview with AD and LN on 4 May 2018).

Information Services. Information services is the process of whether or not the public getting the information. This process can be categorized into two processes, namely through a request and without a request. Information services which do not require a request from users can be found available online through websites or social media, again without the need to be specifically requested. Observation results found that there is information from BPBD South Sulawesi that is available without requests online, i.e. strategic plan and work plan of BPBD South Sulawesi. Both documents can be downloaded freely on PPID South Sulawesi website. Other information that can be freely accessed is information on disaster events. This information 
is available on social media Facebook BPBD South Sulawesi and on the website Data and Information Disaster Indonesia (DIBI) BNPB. In addition, disaster information is also published through the Pusdalops South Sulawesi application and social media managed by BPBD South Sulawesi.

Information services that require special applications can be done through online media and can also be done by delivering direct application to the office of BPBD South Sulawesi. Services through online media can be accessed on PPID website of South Sulawesi Province. However, the online media is not yet convincing to be a means of soliciting public information. The argument underlying this assumption is that information services are the tip of the information management process. Meanwhile, the processes in the previous stages have not been reliable. In addition, as revealed in the beginning, public information managers still do not know the duties and roles expected of him as the management of public information.

\subsection{Open Government in Disaster Information Management}

Transparency, participation and collaboration are the principles of Open Government. These principles are found in the management of disaster information. But not all stages in the management of public information are found in these values. Management of public information is carried out through the stages of gathering, classifying, documenting, and providing information services. In gathering information, the government carries out transparently through delivery in meetings with various disaster stakeholders and provides a format for reporting on disaster events that can be accessed by all parties. Public participation can be in the form of delivery of disaster information through the Pusdalops South Sulawesi application or through information on social media. The collaboration was found in the process of collaboration between the BPBD and various other government agencies, the private sector (DVAT Australia) and NGOs engaged in the field of disaster. At a later stage, the value of collaboration is found at the information service stage. In this case, South Sulawesi BPBD collaborates with PPID and DIBI BNPB as a means of delivering public information. Meanwhile, disaster information can also be accessed through the PUSDALOPS SULSEL application which is the result of collaboration with DVAT Australia. For the information documentation stage, the South Sulawesi BPBD collaborated with the DIBI BNPB for online data documentation.

On the other hand, at the stage of information classification, transparency, participation and collaboration principles have not yet been found. The main reason that can be identified is because this stage has not been implemented well in the management of public information in the South Sulawesi BPBD. In summary, the link between the principles of open government and the stages of information management can be seen in Table 1 below:

Table 1. The relationship between the principles of Open Government with Public Information Management

\begin{tabular}{|c|c|c|c|}
\hline \multirow{2}{*}{$\begin{array}{l}\text { Public Information } \\
\text { Management }\end{array}$} & \multicolumn{3}{|c|}{ Open Government Principle } \\
\hline & Transparency & Participation & Collaboration \\
\hline $\begin{array}{l}\text { Gathering } \\
\text { Information }\end{array}$ & $\begin{array}{l}\text { Submission } \\
\text { through } \\
\text { WhatsApp groups } \\
\text { and meetings with } \\
\text { various disaster } \\
\text { stakeholders }\end{array}$ & $\begin{array}{l}\text { Submit } \\
\text { information on the } \\
\text { disaster of the } \\
\text { Pusdalops South } \\
\text { Sulawesi }\end{array}$ & $\begin{array}{l}\text { Collaborate with government } \\
\text { agencies, NGOs and DVAT } \\
\text { in compiling documents and } \\
\text { gathering information }\end{array}$ \\
\hline
\end{tabular}




\begin{tabular}{llll}
\hline & Not found & $\begin{array}{l}\text { application and } \\
\text { social media } \\
\text { Not found }\end{array}$ & Not found \\
$\begin{array}{l}\text { Classifying } \\
\text { information } \\
\begin{array}{l}\text { Documenting } \\
\text { information }\end{array}\end{array}$ & Not found & Not found & DIBI BNPB Website \\
$\begin{array}{l}\text { Providing } \\
\text { information }\end{array}$ & Not found & Not found & $\begin{array}{l}\text { PPID South Sulawesi } \\
\text { website, DIBI BNPB } \\
\text { website, Pusdalops South } \\
\text { Sulawesi application }\end{array}$ \\
\hline
\end{tabular}

From Table 1 it can be seen that the most dominant value of Open Government found in the management of disaster information in BPBD South Sulawesi is the principle of collaboration.

This is influenced by several things including: (1) disaster information can be sourced from various parties other than the government. The results of the study showed that information on many disaster events was sourced from the community and NGOs in the regions. This encourages BPBD to collaborate with various parties. (2) Institutionally, disaster management is not only the full responsibility of BPBD. In addition to BPBD, social services, BMKG, Public Works, SAR, TNI, POLRI and a number of NGOs also have a role in disaster management. For this reason, BPBD needs to collaborate with various other institutions, and (3) disaster management requires a lot of specific expertise that is not always possessed by HR at BPBD such as making applications and websites, making disaster prone maps etc. In overcoming this problem, BPBD collaborated with DVAT Australia to create a website and application for Pusdalops, as well as universities for making disaster prone maps.

In general, South Sulawesi BPBD has tried to promote information disclosure through the website as implemented by many parties. But these efforts have not been optimal. As an alternative, the South Sulawesi BPBD uses more practical media accessible to users and sources of disaster information such as radio and social media. It is social media that is a medium of transparency that encourages community participation in disaster information management in South Sulawesi.

From the aspect of disaster management, the disaster management cycle must be seen as a complete process from mitigation to recovery. Criticism that is widely conveyed to the mass media in general is only to focus on covering disasters when there are disasters. One of the findings of this study shows that the same problem in the management of disaster information by the Government Agency responsible for managing public information was also found. Disaster events are still more dominantly managed better by the Regional Disaster Management Agency than information about mitigation, preparedness, or rehabilitation and reconstruction of disasters. This can be seen at the stage of information gathering, documentation, and information services. At all stages of information management, information on disaster events that looks more coordinated data collection, more complete documentation of the data, as well as more information on disaster events is easier to obtain in various media. This is in contrast to information on mitigation, preparedness, rehabilitation and reconstruction. 


\section{Conclusion}

The principles of Open Government can be found in the management of disaster information in South Sulawesi. South Sulawesi BPBD is most open in the stages of gathering public information. All open government principles can be found at this stage. Besides that, at the information service and information documentation stage, the principle of collaboration with various parties was identified. In contrast, the principles of open government are not identified at the information classification stage. This is due to the fact that this stage has not been well implemented in disaster information management.

The principle of collaboration is most widely applied in disaster information management. This is caused by three things: (1) disaster information can be sourced from various parties other than the government (2) disaster management is not only the whole responsibility of BPBD so it is necessary to collaborate with various other institutions, and (3) disaster management requires a lot of specific expertise that is not owned by BPBD. In managing disaster information, information on disaster events is better managed than information on prevention, preparedness, and rehabilitation and reconstruction by the South Sulawesi Regional Disaster Management Agency.

\section{References}

[1] McDermott, P.: Building open government, Gov. Inf. Q (2010)

[2] Lathrop, L., Ruma, D.: Open government: Collaboration, transparency, and participation in practice. O'Reilly Media, Inc (2010)

[3] Wirtz, B M and Birkmeyer, S.: Open Government: Origin, Development, and Conceptual Perspectives, Int. J. Public Adm., Vol. 38, no. 5, pp. 381-396 (2015)

[4] A. J. Meijer, A J, Curtin, D and Hillebrandt, M.: Open government: Connecting vision and voice, Int. Rev. Adm. Sci (2012)

[5] Janssen, M., Charalabidis, Y and Zuiderwijk, A.: Benefits, Adoption Barriers and Myths of Open Data and Open Government, Inf. Syst. Manag (2012)

[6] Schumann, W. R. : Transparency, governmentality, and negation: Democratic practice and open government policy in the National Assembly for Wales, Anthropological Quarterly (2007)

[7] Coglianese, C.: The transparency president? the Obama administration and open government," Governance (2009)

[8] Bedini, I, Farazi, F, Leoni, D., Pane, J., Tankoyeu, I and Leucci, S.: Open Government Data: Fostering Innovation, JeDEM - eJournal eDemocracy Open Gov (2014)

[9] Dawes, S. S and Helbig, N.: Information strategies for open government: Challenges and prospects for deriving public value from government transparency, in Lecture Notes in Computer Science (including subseries Lecture Notes in Artificial Intelligence and Lecture Notes in Bioinformatics) (2010) 